\title{
Learning beyond the classroom: biomedical science students' narratives of volunteering and developing employability skills
}

\author{
Sheila Cunningham \\ Middlesex University, UK \\ Deeba Gallacher \\ Middlesex University, UK
}

\begin{abstract}
This case study focuses on a work that developed from a Higher Education Academy (HEA) teaching development grant which investigated biomedical science undergraduate students' experiences of engaging with health related volunteering opportunities and the link with maximising employability skills in a North London university.
\end{abstract}

Biomedical students recognise theoretical knowledge and practical skills as essential to employability but have limited opportunity to apply these, with sparse placement opportunities, especially within hospital or laboratory environments. Graduate employability skills are generally accepted as the knowledge, skills and attributes to be effective in the workplace. Reports on graduate employability highlight communication skills, team-working, integrity, intellectual ability and self-confidence as the five most important attributes sought by employers (Archer and Davidson, 2008). NHS Careers (2012) expands this (biomedicine profile) by including creativity, initiative and flexibility, and with what could also be argued as important: wisdom (Schwartz, 2012). This is a tall order for any curriculum and in reality embraces more than classroom or laboratory learning environments, but the whole undergraduate experience. This particular work was a partnership endeavour with undergraduate students to seek science related volunteering opportunities and the potential for developing the skills for biomedical employability.

The methodology in this case study was primarily action research with its iterative cycles. These were: identification and development of science or health volunteering opportunities, employers' perceptions of the use and value of such volunteering, and 
articulation of the skills and qualities from such experiences. One key 'data' output was a record of students' reflections and narratives as they contributed and drove the volunteering activity. Students maintained diaries of their experiences, skill development, personal growth and achievements, and of working in partnership with staff and independently. Students' reflective blogs revealed several benefits and challenges and their approaches to address these illustrate their creativity, endurance and flexibility. This 'snap-shot' presents 'voices' or 'narratives' of partnerships which enhance the students' learning (and teaching) experience. It also presents students' attitudes to volunteering and how they feel this contributes to their employability potential. Insights gained are invaluable to academic staff in appreciating the social construction of learning and the extension of formal academic provision into the third sector.

Keywords: volunteering; employability skills; biosciences.

\section{Introduction}

Gaining employment is a priority for the majority of students (CBI, 2009) so much that candidates have to find new ways to distinguish themselves to potential employers to help stand out from the crowd. Whilst employers rate STEM (science, technology, engineering and maths) subjects highly for their technical competency, analytical problem-solving, numeracy and intellectual rigour skills (Toland, 2011), there still emerges a varied picture of employability and employment opportunities. The change in employer focus from a good degree to a good degree plus additional, softer skills and attributes, means that Higher Education Institutions (HEIs) are having to review their provision to students. Many HEIs have a diverse range of students from both the UK and overseas, with varying needs and looking for careers in a range of sectors. Students recognise competition in the workplace and increasingly desire and seek to develop skills and gain practical experience in order to both develop and to be viewed more favourably by employers. Therefore practice-based applications, such as placements, internships and volunteering, are ever more popular as a recognised way to help to develop practical work experience and gain a step on the career ladder. Undergraduates are faced with a number of options but are frequently bemused or limited in what they can engage in and how, and also at times unclear about what gains and benefits could be accrued. 
This case study, developed from a Higher Education Academy (HEA) Teaching Development Grant (TDG), aimed to explore extra-curricular volunteering opportunities as a means to maximise employability skills for health related students (initially biomedical science undergraduates). There are opportunities in existence which can be utilised or developed further which use subject specific knowledge and clinical skills, but these are currently not exploited or developed within this North London university. Placement is integral in some health programmes for students (e.g. Nursing, clinical physiology, etc.), however, locally for biomedicine it is restrictive and thus highly competitive. Students recognise theoretical understanding and practical skills as essential to employability but hold frustrations at the placement limitations and the limited opportunity to apply these theoretical understandings in a practical way.

The key questions which were the drivers were:

- What opportunities for health related volunteering are there locally?

- What are the benefits of undertaking volunteering activities?

- How do biomedical students view the term 'employability' and how to develop this?

This work was more extensive than intended and presented here. It addressed several wider questions than those above but, for the purpose of this paper, will focus only on those identified above. The aims of the wider project are to inform the university locally (and more widely) whether there are specific volunteering routes to enable health or biomedical students to use their specific knowledge and develop their skills. Furthermore, it also aims to explore how this can be embedded within the programme or university volunteering system.

\section{Context}

\section{The current economic climate - effects on graduate recruitment}

Work experience is one of the biggest drivers behind employability, with over half the employers surveyed in the High Flyers' Graduate Market Report (2012) indicating that graduates with no work experience were unlikely to be offered graduate employment. 
The Association of Graduate Recruiters (AGR) annual summer survey shows that some leading UK employers are receiving on average 85 applications for each job. Competition is fierce with some sectors increasing vacancies and others decreasing, with an overall decrease of approximately 4\% (AGR, 2013). Because of the high volume of applications, employers are increasingly looking for additional ways to select the right applicants for their roles and this has led to the identification of 'employability' skills, such as commercial awareness, communication, problem solving, numeracy, literacy and IT skills (see Pegg et al., 2012).

Although there is an increase in students entering STEM discipline subjects at HEls, there is still a lack of graduates for the employment market. This, it seems, is compounded by concerns around 'work readiness' or perceptions or possession of the knowledge, skills attitudes and awareness to make contributions to a workplace (Mason et al., 2006) which is already more challenging than that faced by their predecessors (Toland, 2011). It is also identified that technical and generic skills - the so-called 'T-shaped' skill set, where the depth of disciplinary knowledge is enhanced by the horizontal ability to apply that knowledge across a variety of work situations, is a valuable asset.

\section{Volunteering opportunities}

Volunteering is any activity in which time is given freely to benefit another person, group or cause (Wilson, 2000), though it is acknowledged that volunteering and volunteers are a heterogeneous group (Bussell and Forbes, 2002). There are multitudes of general volunteering opportunities within universities and the local community but not necessarily focused on health or bioscience. Biomedical science degrees do not necessarily have automatic professional recognition requiring appropriate experience and submission of the required portfolio for registration with the Health and Care Professions Council (HCPC) (NHS Careers, 2012). The opportunity to obtain employment to secure this is also highly competitive, with the potential for some students to seek other career routes. Volunteering or community engagement has been embedded more so in the USA academic institutions than in the UK. In the main referred to as 'service learning', this aimed to harness civic engagement of students within the community, building a sense of 'citizenship' and arguably also providing an opportunity for 'transformational potential' within the individual (and the community itself (Butin, 2006, p.474). In the UK it appears to lack the same 
cohesion and structure which, as Holdsworth (2010) identifies, results in a variety of assumptions about what it can achieve and who benefits.

This work evolved from students' frustrations at limited placement opportunities, informal conversations in class about volunteering experiences, and various applications of immunological and biotechnology techniques in healthcare research and treatment. This project was organic in that it grew from a perceived need and joint interest from students and academic staff to address that need. In essence, it focused on science (or health) related volunteering opportunities which could enable students to utilise their knowledge and laboratory skills to develop their employability skills. Students' recognised and engaged with health-related volunteering but were keen to use their scientific knowledge and skills; this indeed was a challenge. What emerged was a partnership endeavour which enabled students to take control of this and embed it within the university's student union system to enhance sustainability.

Holdsworth and Quinn (2010) identify that study or career related volunteering was more common among medical and social science students, and among 'non-traditional' students. Whilst benefits for the individual are acknowledged, there are criticisms of whether benefits to communities are realised (Heath, 2007) and if a more sinister side of volunteering is to replace or 'fill-in' paid employment or just accrue experience. The relationship between volunteering and employability reflects a growing emphasis on 'economies of experience' and the translation of cultural capital into personal capital (Heath, 2007). However, motivations to volunteer are complex. Whilst Holdsworth and Quinn (2010) suggest some motivations are instrumentalist and strategic, Wilson (2000) earlier suggested altruism or 'caring' to be strong motivators.

\section{Locally}

Placements for biomedical students are sparse, reliant on local availability with a ratio of placements to applicants averaging 1:10. Anecdotally students felt frustrated and lost, keen to gain experience but lacking realistic opportunities. This HEl is a large post 1992 university with the characteristic diversity of its many counterparts: whites $22.1 \%$, black 28.3\%, Asian 31\%, Chinese 0.9\%, with females comprising 60.2\%. Many students do hold part-time jobs to sustain themselves financially. Holdsworth's (2011) research identified 
that volunteering rates were higher among some minority groups, which could explain the enthusiasm of those from the case study institution.

\section{Methodology}

The methodology was based on an action research approach which comprised three cycles of assessment, intervention/action and evaluation. Characteristics of Action Research, as identified by Reason and Bradbury (2006, p.2-3), that are demonstrated in this research include; research undertaken in the community involved with participation from all stakeholders in the questioning, and sense-making informing the research and the actions undertaken. It uses feedback from data in an ongoing cyclical manner, focuses on problems that are of immediate concern to practitioners, frequently uses cases study, is formative in that it has a problem but aims and methodology may be adjusted during the process, and includes evaluation and reflection.

The first cycle involved investigating the range of volunteering opportunities locally (within and outside of the university), relating to health disciplines. Further cycles looked at students' perception of employability, volunteering and employability skills (focus group and questionnaires). The work utilised focus groups, reflective diaries and questionnaires of the wider student body. Data yielded both qualitative and quantitative data not all of which is reported here.

\section{Stages}

A steering group of eight students and one lecturer was convened. This was not part of the curriculum and it was explained to students that they would not get credits or any other academic recognition for this, so participation was purely voluntary and in their own time on top of other demands. They readily agreed to this.

Following initial explorations, the students' steering group found a charitable organisation which they wished to work with but was not set up within the university. They then devised a strategy to investigate the work and requirements further, and set this up themselves. This was an organisation the lecturer had some knowledge and involvement with but did not want to lead the students nor set it up for them. This was purposeful since it was 
concluded that in order to feel ownership, students needed to both establish and develop it whilst the lecturer assisted. The relationship evolved to one where the students became increasingly independent and self-sufficient, requiring decreasing input from the lecturer as time passed. The steering group members kept diaries or blogs of their experiences which were kept confidentially and identity removed to ensure anonymity. This was in accordance with the local ethical procedures and with the full consent of the students. The biomedical students established contact with a national charity to establish volunteering work (fundraising and recruiting volunteers to the bone marrow register). Students completed training from the parent charity and abided by their guidelines. The students held donor recruitment clinics, fundraising and awareness raising events within the HEI and outside in the local community. The student diaries detailing these experiences were analysed textually, though this was challenging as they were rather brief at times and the levels of reflection varied.

\section{Student narratives}

\section{Benefits of volunteering}

Students were willing to be part of setting up volunteering but initially were reluctant to do this without support. The 'partnership' which initially emerged was one of being led by the lecturer and passivity on the part of the student. The role of the lecturer was geared to reflect the higher levels of engagement in the ladder model outlined by Hart (1992) to avoid tokenism or 'decoration', effectively non-participation. This model of participation developed from Arnstein's seminal (1969, cited Hart, 1992) theoretical work on community participation and citizen empowerment. Hart focused on young people participation in relation to adults, with the highest level outlined as 'shared decision making' or full involvement and control (see Figure 1), which was a key operational aim in this research. Students developed a number of skills and attributes, particularly increasing independence, with more control and decision making as they developed confidence. 
Figure 1. Hart's Model: Ladder of Participation (1992).

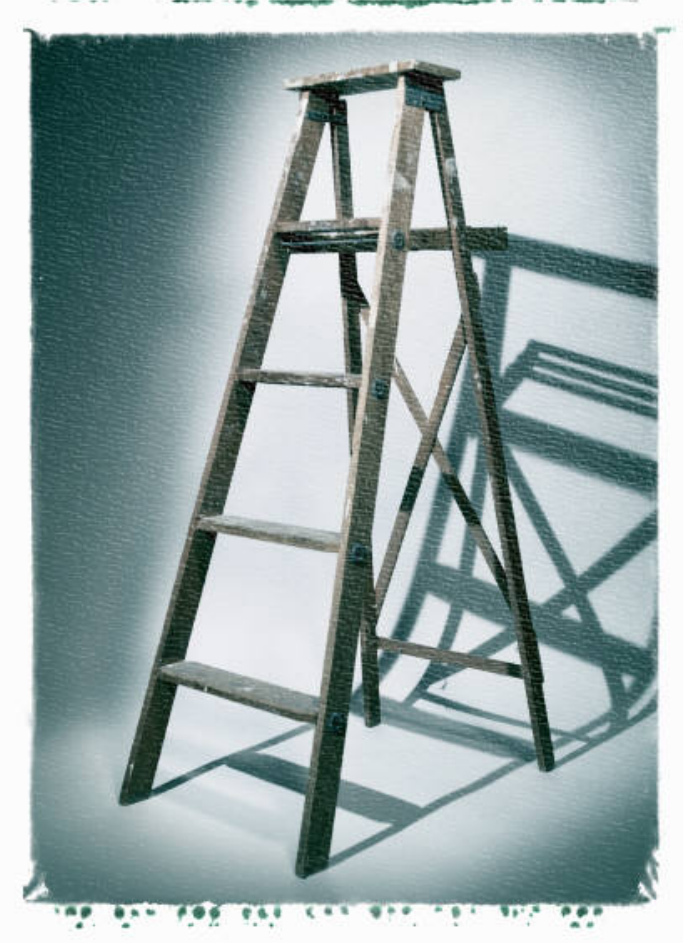

\begin{tabular}{|c|c|}
\hline $\begin{array}{l}\text { 8. Shared decision making } \\
\text { and control }\end{array}$ & \multirow[t]{3}{*}{ Degrees of participation } \\
\hline $\begin{array}{l}\text { 7.Young people lead and } \\
\text { initiate action }\end{array}$ & \\
\hline $\begin{array}{l}\text { 6. Partnership: shared } \\
\text { decisions with young people }\end{array}$ & \\
\hline $\begin{array}{l}\text { 5. Young people consulted } \\
\text { and informed }\end{array}$ & \multirow[t]{3}{*}{ Degrees of tokenism } \\
\hline $\begin{array}{l}\text { 4. Youth assigned and } \\
\text { informed (consulted) }\end{array}$ & \\
\hline $\begin{array}{l}\text { 3. Tokenisation: informed of } \\
\text { action }\end{array}$ & \\
\hline $\begin{array}{l}\text { 2. Decoration: not active } \\
\text { involvement adult led. }\end{array}$ & \multirow[t]{2}{*}{ Non participation } \\
\hline $\begin{array}{l}\text { 1. Manipulation: appears } \\
\text { youth inspired but feigned. }\end{array}$ & \\
\hline
\end{tabular}

We have allocated roles amongst each other, $\mathrm{XXX}$ as treasurer and $Y Y Y Y$ as Secretary and I'm the President. This has been confirmed by all of us for the time being, if you suggest otherwise please inform us. (Oriana)

Surprisingly, 'employability skills' featured relatively low as a motivation for volunteering but was mentioned, although students did see the added bonus of skills development. They identified with aspects of the enhancement and career functions but were primarily motivated by giving back and helping others, as expressed by these students:

I do this because I was to make a difference and help people who cannot help themselves. (Oriana)

Personally, volunteering enhances my confidence, my motivation to pursue my career within the health profession and enables me to aid people who are unable to help themselves. (Terfera) 
This is similar to Holdsworth's (2011) findings as she found the most common reason given was 'volunteering to help someone or their community'. Furthermore, employmentrelated reasons were more important for students from non-traditional backgrounds.

Students' diaries $(n=6)$ varied in level of reflection and detail. The key issues which emerged were recognising key achievements, approaching problems, personal gains and emotional investment. Positive effects were evident: personal gains; altruism and community engagement; problem identification and solving; demonstrating resilience and, in some instances, creativity.

Moving on, perceived success by the group is evident in this successful bid for a local Student Union recognition award:

Alongside our lecturer we set up a, this [Charity] Society only a year ago and have beaten all our targets in recruitment and fundraising this year. Marrow [charity] group is known for its large diversity of ethnic groups; and our student society has put this to good use, and has demonstrated to London Universities, how we are determined to save lives. Our society is the best in respect to giving the most opportunities for gaining skills and bringing students out their shells in public speaking, getting involved in group work, coordinating and developing organizing skills. (Oriana)

\section{Recognising achievements}

Students reported a number of achievements including communication, confidence but also using their initiative.

We have over 300 bone marrow donors signed up and 100 volunteers in the matter of 6 months!...[we are] connected to all our members, organizing [clinic] events, public speaking in Primary schools and Secondary schools. Fundraising has also been key to this society and has taken place at many of the events over the year. (Anna) 
Several other benefits are also identified and could be summarised as:

- Learning new skills.

- Building confidence and self-esteem.

- Establishing new friendships.

- Making personal networks.

- Feelings of worth (contributing to society).

- Developing a better understanding of themselves.

- Enriching other people's lives.

Many of the skills expressed are reflective of those identified in the employability profile on the NHS Careers (2012) site (biomedical science). This also echoes the perception of the 'win: win' benefit, even if from a limited perspective (Holdsworth and Quinn, 2010).

As a biomedical science student, it would be useful to get some more experience and knowledge in the field. It's also useful to put onto my CV as extra-curricular activities help to make an individual to stand out from the masses of graduates that compete for jobs... (Chris)

The [charity] AGM really did bring home how important the work we were now involved in was. It also drove home the massive success... (Tobe)

\section{Personal gains and growth}

Challenges emerged: parity of student engagement varied which led to tensions among the students. Organisation structures and processes were fraught at times but did not deter from their task:

...the Fresher's fair was full of hitches, room booking, our supplies did not arrive and people seemed confused...it seemed like it would be a disaster but somehow it turned out fine... (Anna)

The details and minutiae of the volunteering they were engaged with did not create a sense of panic or disengagement but of problem solving, demonstrating maturity and in some cases, leadership. There was a sense of the group coming together with the central 
goal as a focus. Students identify with 'growth' during this period, which in some ways are illustrative of Holdsworth and Quinn's (2010) acknowledgment of a period of change or 'liminality' evident in volunteering among university students.

...it is a self-satisfying experience that anyone would enjoy! (Terfera)

Our course is quite segmented and everyone has their own friendship groups and they do their own things, we don't do things together. Marrow is one place where we have been able to come together which has worked out well. (Chris)

This reflects a sense of Turner's (1977) concept of liminality of passing through stages of maturation and developing their identity as students and adults. Transition through university, especially year 1 , heightens this. Some students identify this journey and also the personal gains and confidence through volunteering.

It was really difficult talking to new people and then having to talk to strangers knowing about the cells and donations helps... it gave me a focus initially...but I do feel better about doing it now I guess my confidence has grown... (Oriana)

As well as bonding with classmates and growing personally, the more complex skills of negotiation and motivation emerged. This was especially true in the earlier stages when roles were carved out and personalities were emerging, culminating in filling in key posts and generating support.

...At the end of the meeting three of us continued to talk and decided that if we were going to set up this [charity] Society, it was now or never! (Chris)

We were given the opportunity to introduce ourselves to the new biomedical science students. This took place before their opening lecture, in a lecture theatre. We were dressed up in our [charity] apparel and looked the part, but I was quite nervous, I do not find public speaking easy, but I wanted to do it, so I just made sure I wasn't the first to speak. (Chris) 


\section{Is volunteering linked to employability?}

This small scale case study shows that students engage with volunteering for a variety of reasons and report multiple and varied achievements and benefits. However, it is unknown whether the science (or health) focused volunteering will lead to 'employability' over and above more generic volunteering. What is certain is that students frequently report confidence and acknowledgement of skills and some (if varied) recognition of the link to employability and employment. The sense of 'growth' and development implies an empowerment whereby they can take responsibility. As those nurturing learning, our role is to support them, especially with articulation of the relevant skills.

Haski-Leventhal and Cnaan (2009) found that participation in voluntary work during undergraduate years enhances students' academic development, life skills development and sense of 'civic responsibility'. In addition, they also report volunteering can help students choose the right vocation for them and improve their curriculum vitae (CVs) and opportunities as they leave university and seek jobs. Student volunteering is also in the interest of academic institutes for building community links but also for developing the underexplored third sector route to employability. Haski-Leventhal et al. (2008) further explain that when students engage in a variety of voluntary activities, the social and cultural life on campus and in the community is enhanced, and overall one could argue the student experience is improved.

\section{Articulating 'employability'}

The students developed and enthused peers to volunteer, recognising this was on top of other demands, both academic and otherwise. Students reported similar understandings of 'employability' reflected in the wider literature base. The focus was on what they had to offer employers but also to demonstrate meeting expectations of employers, or what they thought was required of them:

I personally think it's putting yourself in the right place to be able to be, um, seen by employers who might potentially want you in the future. Like getting yourself voluntary work... work experience, just doing something that will make you stand out and show that you've the good skills and qualities for that job. (Anna) 
The organisations, they want you to be experienced in some sort of fields of it, to have a feel of what it is and they actually prefer people to have some sort of skill in order to show that they're determined to do that job. (Naeem)

When asked what they meant by this it was evident that this was conceptualised in a number of ways. Students identified it as a sizeable assortment of skills but also complying to what employers wanted:

I think it's, like, showing yourself that you're the one to have that job and the more skills you have, the more chance you have of being chosen. (Naeem)

Students had trouble imagining their future careers but focused on laboratory based work, research, or further studies. However, the means to achieve that potential future was not clearly thought through. They did, however, acknowledge 'generic' skills and qualities which would fit a range of careers, identifying how they saw some of these, namely communication and team working, developing in the university classes at the same time as they acquired disciplinary knowledge.

Yes, I would agree. Like, the last PBL [problem based learning] that we had to do, in groups, because it was a group effort, everyone had to do input and because it had questions everyone had to answer and things like that and put them together. So yeah, we are learning a lot about communication skills and being able to work with each other. (Tobe)

From these findings, students appeared to take ownership of their employability, acknowledging it as their responsibility, although they did see it as involving many within the curriculum, demonstrating the strong ties of curriculum and employability as demonstrated in literature (Pegg et al., 2012). Harvey (2003, p.1) suggested that employability was not merely 'getting a job'. He proposed, 'employability is more than about developing attributes, techniques or experience just to enable a student to get a job, or to progress within a current career. It is about learning and the emphasis is less on 'employ' and more on 'ability”, a sentiment echoed by Yorke (2006) who suggests employability emphasises continuous development. Ultimately the emphasis is on developing critical, reflective abilities, with a view to empowering and enhancing the learner. 
The range of skills and human capital uncovered from the small group of students reflects the wider skill set identified by employers. Data collected by the Biosciences Subject Centre (Anderson and Mitchelle, 2006) and from Blackford et al. (2006) assert the skills and qualities for biosciences are:

1. Self-management skills (self-promotion, self-awareness, networking, accepting responsibility, leadership).

2. People skills (team-working, communication, negotiating/persuading, customer service).

3. General skills (problem-solving, entrepreneurial, IT skills, numeracy, commitment, creative thinking).

4. Specialist skills (specific occupational skills, technical skills).

5. Business and commercial awareness.

Data from students here demonstrates that volunteering has helped to develop all five strands of these skills and qualities, as well as ownership and control. Stuart et al. (2009, p.5) assert that university lecturers ought to look to broaden experiences on their courses and place value on the 'whole lives' as beneficial to future employment.

\section{Conclusions}

When considering what has been learned from this project thus far, a number of things can be identified. Although students recognised the onus is on themselves to develop their employability skills, they also saw the importance of the support from the university and importance of the curriculum in developing employability. Engagement with volunteering activities does foster these skills and the use of health or science related avenues enhances the use of disciplinary knowledge, if not directly, then indirectly in providing confidence to partake in events. Students avidly undertook the challenge of volunteering and of setting up one specific charity society (group), and from the earliest stages demonstrated enthusiasm and independence. This extra-curricular work provided an opportunity for them to create a unique identity within the university and, as they were setting this up from nothing, could set their own expectations and targets. 
Key benefits identified by students included gaining in confidence, presenting/ communicating effectively and appropriately to different audiences, and problem solving: 'thinking on their feet'. What was noted is that these students formed social cohesion and independence fairly quickly and became a self-sustaining group, no longer requiring close guidance from the lecturer, instead taking direction from the parent charity. Although there was no mention of their studies in their diaries, this was an issue frequently discussed at meetings and also at 'clinic' events. The disciplinary knowledge base gave them the sense of 'authenticity' for knowing some of the theory and of doing the practical work of the charity in raising awareness and recruiting donors. This reflects the findings of Braime and Ruohonem (2011) who found a large proportion of their students identified a close link with academic work and volunteering. This could be argued as functional or instrumental, but in this instance it appears to be a confidence booster to enable engagement.

What the work fails to tell us so far is 'difference'. What is gained from volunteering compared to what is gained from a formal structured work placement and how the two can be bridged. What is known is that with employability increasingly in focus, HEls will have to consider additional routes to practice based work alongside that of the placement.

\section{References}

Anderson, J. and Mitchelle, H. (2006) Employability for students. Briston: HEA and Escalate. Available at:

http://www.cumbria.ac.uk/Public/Education/Documents/Research/ESCalateDocume nts/EmployabilityForStudents.pdf (Accessed: 9 April 2013).

Archer, W. and Davison, J. (2008) Graduate employability: what do employers think and want? UK: The Council for Industry and Higher Education.

Association of Graduate Recruiters (AGR) (2013) Recruitment survey 2013: summer review. CFE and Association of Graduate Recruiters.

Blackford, S., Burdass, D. and Assinder, S. (2006) 'Student employability - whose job is it?', Centre for Bioscience Bulletin 17, Spring 2006, pp. 6-7 (from Education Committee, Bioscience Federation). 
Bradbury, P. and Reason, H. (2006) Handbook of action research. London: Sage.

Braime, J. and Ruohonem, M. (2011) Exploring impacts of volunteering on university students in London. The National Coordinating Centre for Public Engagement \& Volunteering England. [Online]. Available at: https://www.publicengagement.ac.uk/sites/default/files/London\%20student\%20volu nteering\%20survey.pdf (Accessed: 15 August 2013).

Bussell, H. and Forbes, D. (2002) 'Understanding the volunteer market: the what, where, who and why of volunteering', International Journal of Nonprofit and Voluntary Sector Marketing, 7(3), pp. 244-257.

Butin, D. (2006) 'The limits of service-learning in higher education', The Review of Higher Education, 29(4), pp. 473-498.

CBI and Universities UK (2009) Future fit: preparing graduates for the world of work. Available at: http://www.cbi.org.uk/media/1121435/cbi uuk future fit.pdf (Accessed: 15 May 2013).

Hart, R. (1992) Children's participation: from tokenism to citizenship. Florence: UNICEF Innocenti Research Centre [Online]. Available at: http://www.unicefirc.org/publications/pdf/childrens participation.pdf (Accessed: 12 August 2013).

Harvey, L. (2003) Transitions to work. York: LTSN. [Online]. Available at:

Haski-Leventhal, D., Ben-Arieh, A. and Melton, G. (2008) 'Between neighbourliness and volunteerism: the participants in the strong communities initiative', Family and Community Health, 31(2): pp. 150-61.

Haski-Leventhal, D. and Cnaan, R.A. (2009) 'Group processes and volunteering: enhancing recruitment and retention', Administration in Social Work, 33(1), pp. 6180. 
Heath, S. (2007) 'Widening the gap: pre-university gap years and the 'economy of experience", British Journal of Sociology of Education, 28(1), pp. 89-103. High Fliers Research (2012) The graduate market in 2012. Available: http://www.highfliers.co.uk/download/GMReport12.pdf (Accessed: 26 November 2013).

Holdsworth, C. (2011) Win, win, win? A critical perspective on student volunteering. Economic and Social Research Council, Institute for Volunteering Research and Birkbeck, University of London Policy Seminar, Thursday 17th March 2011. Available at:

http://www.esrc.ac.uk/ images/Prof\%20\%20C\%20Holdsworth\%20\%20Summary tc m8-15079.pdf (Accessed: 3 October 2013).

Holdsworth, C. and Quinn, J. (2010) 'Student volunteering in English higher education', Studies in Higher Education, 35(1), pp. 113-127.

Mason, G., Williams, G. and Cranmer, S. (2006) 'Employability skills Initiatives in higher education: what effects do they have on graduate labour market outcomes?' Education Economics, 17(1), pp. 1-30 [Online]. Available at: http://aces.shu.ac.uk/employability/resources/061006 91251.pdf (Accessed: 10 October 2013).

NHS Careers (2012) Biomedical Science. http://www.nhscareers.nhs.uk/explore-bycareer/healthcare-science/careers-in-healthcare-science/careers-in-lifesciences/biomedical-sciencel (Accessed: 20 March 2013).

Pegg, A., Waldock, J., Hendy-Isaac, S. and Lawton, R. (2012) Pedagogy for employability. York: HEA. Available at: http://www.heacademy.ac.uk/assets/documents/employability/pedagogy for emplo yability update 2012.pdf (Accessed: 7 February 2013). 
Schwartz, S. (2012) 'Employability skills - where is wisdom?', The Guardian, Higher Education Network, 2 May (Online). Available at: http://www.theguardian.com/higher-education-network/blog/2012/may/02/wisdomas-an-employability-skill (Accessed: 28 November 2013).

Stuart, M., Lido, C., Morgan, J. and May, S. (2009) Student diversity, extra-curricular activities and perceptions of graduate outcomes. Higher Education Academy. Available at:

http://www.heacademy.ac.uk/assets/documents/resources/publications/Stuart ECA Final.pdf (Accessed: 13 October2013).

Toland, A. (2011) HE STEM employability skills review. National HEA STEM Programme. Available at: http://www.hestem.ac.uk/sites/default/files/employability skills review.pdf (Accessed: 10 June 2013).

Turner, V. (1977) The ritual process. Ithaca: Cornell University Press.

Wilson, J. (2000) 'Volunteering', Annual Review of Sociology, 26, pp. 215-240.

Yorke, M. (2006) 'Employability in higher education: what it is - what it is not', Learning and Employability Series 1 and 2. York: HEA.

\section{Author details}

Sheila Cunningham is a Principal Lecturer and Senior Teaching Fellow in the School of Health \& Education, at Middlesex University. Her research interests are in enhancing teaching-learning environments, particularly in health related professional development programmes in higher education. She is currently interested in student diversity and inclusivity and how this can be harnessed to expand the student experience and opportunities. Sheila is also interested in enhancing the use of third sector experiences to expand skill development. 
Deeba Gallacher is a Senior Researcher in the Centre for Learning and Teaching at Middlesex University. Her interests are the first year experience and the transition and retention of students. Deeba is also interested in the student experience and researches various pedagogical issues of inclusivity and student achievement. 